\title{
Combinatorial synthesis of fluorescent trialkylphosphine sulfides as sensor materials for metal ions of environmental concern
}

\author{
M. Castillo and I.A. Rivero* \\ Centro de Graduados e Investigación, Instituto Tecnológico de Tijuana, \\ Apartado Postal 1166. 22000, Tijuana, B.C. México \\ E-mail: irivero@tectijuana.mx
}

(received 12 Nov 03; accepted 13 Jan 03; published on the web 17 Jan 04)

\begin{abstract}
A combinatorial library of diverse alkyl-phosphine sulfides bound to Merrifield, Argopore, Argogel and Wang resins was synthesized and evaluated for their sensing properties. The library consists of 12 products with the anthranyl group as a fluorophore and phosphine sulfide alkyl derivatives as receptors of transition and heavy metal ions. The fluorescence spectral characteristics and the properties as sensing phase of these materials towards $\mathrm{Pb}(\mathrm{II})$ and $\mathrm{Cu}(\mathrm{II})$ were established.
\end{abstract}

Keywords: Combinatorial library, solid phase, sensors, fluorescence

\section{Introduction}

Solid phase organic synthesis is nowadays a well-established tool for the production of combinatorial libraries. While much research has been directed toward new drug and pharmaceuticals discovery, the field of developing new materials for chemical sensing has been scarcely addressed. ${ }^{1}$ Although this approach has achieved much progress, it suffers from disadvantages such as tedious and time-consuming procedures, low reproducibility and limited number of synthesized materials. With the advent of combinatorial chemistry a new strategy is currently emerging, which may increase the rate of investigation of chemical sensing materials. ${ }^{2}$ The attractiveness of this technique lies in the possibility of covering a desirable range of properties, in the large number of unique sensors that can be obtained each time, and in its dependence on the limited number of starting materials.

The production of sensing devices for the detection and measurement of different metal ions is of great importance in chemistry and biology. We have taken into account the growing interest in the synthesis of molecules capable of performing logical operations and their ability to detect the presence of transition and heavy metal ions. ${ }^{3}$ Most of the systems reported are based either on the quenching of fluorescence ${ }^{4}$ or the enhancement of fluorescence. ${ }^{5,6}$ It is also known that the selective interaction of transition and heavy metal cations is achieved by receptors containing sulphur or nitrogen. ${ }^{7,8}$ Triisobutylphosphine has been used as a carrier in solvent extraction and solid supported liquid membranes. ${ }^{9-11}$ It has been demonstrated that the reaction equilibrium for the coordination of 
ligands to form a monomeric complex, is similar to that occurring internally with polymers which contain the same binding ligand. ${ }^{12}$ A polystyrene support was covalently bonded to the anthracene molecule which has been used as the fluorophore, and a phosphine sulfide group attached to anthracene as a recognizing receptor.

Recently, we developed a library of resin-dansyl-phenylboronic acids bound to Merrifield resin as selective sensors for fructose, which is 200 times more selective for fructose than glucose. ${ }^{13}$ Following with the search of novel sensors supported on solid phase, we have investigated the synthesis of fluorogenic receptors for copper and lead through a combinatorial approach. In this paper we describe the synthesis of a phosphine-sulfide-anthracene sensor library for $\mathrm{Cu}(\mathrm{II})$ and $\mathrm{Pb}$ (II) metal ions. According to the synthetic route outlined in Scheme 1, we chose three phosphine sulfide derivatives and four solid supports (Merrifield, Argopore, Argogel, and Wang resins). The fluorescence spectral characteristics of intermediates and final products supported on the various resins and their behavior as sensing phases were studied. The solids $(3,4,5,6,7)$ were analyzed on a FIA system to determine the fluorescent response to the metals; only the product $\mathbf{7}$ showed to be sensitive to the presence of metal ion solutions.

\section{Results and Discussion}

\section{Design and synthesis of the fluorescent sensor library}

Our synthetic route (Scheme I), involves the initial reaction of anthraquinone with $\mathrm{Me}_{3} \mathrm{SI}$ in the presence of $\mathrm{NaH}$ and DMSO as the solvent at $93{ }^{\circ} \mathrm{C}$ to obtain the first intermediate, 9,10anthracenediepoxide (1). Intermediate 1 reacts with $\mathrm{KI} / \mathrm{LiBr}$ to generate 10 -methanol-9-anthracene carboxyaldehyde (2). ${ }^{14}$ The next reaction involves the coupling of 2 to the resins Merrifield, Argopore-Cl, Argogel-Cl and Wang-Cl through a nucleophilic displacement of chloride in the presence of THF/NaH to yield the resins-10-oxymethyl-anthracene-9-carbaldehyde (3a-d). Then, $\mathbf{3}$ is reduced with $\mathrm{NaBH}_{4}$ to produce PS-10-oxymethyl-anthracen-9-yl)-methanol (4a-d). The chlorination reaction is carried out in the presence of triphosgene (BTC)/triphenylphospnine ${ }^{15}$ to obtain the chlorinated resin derivatives PS-10-oxymethyl-9-chloromethyl-anthracene (5a-d). The chlorinated resins were treated with phosphine Grignard ${ }^{16}$ previously prepared in THF to obtain PS10-oxymethyl-9-(diisobutyl-phosphine oxide-methyl)-anthracene (6a-d). Finally, reaction of the phosphine resins with $\mathrm{P}_{4} \mathrm{~S}_{10}$ in DMA as solvent to replace the oxygen by sulphur gave the desired immobilized PS-10-oxymethyl-9-(diisobutyl-phosphine sulfide-methyl)-anthracene (PS-anthracenephosphine sulfide materials (7a-d). The phosphine sulfides were synthesized in good conversion yields (64-75\%). The final products were washed with THF/ DCM/ MeOH and dried under high vacuum for $12 \mathrm{~h}$. 

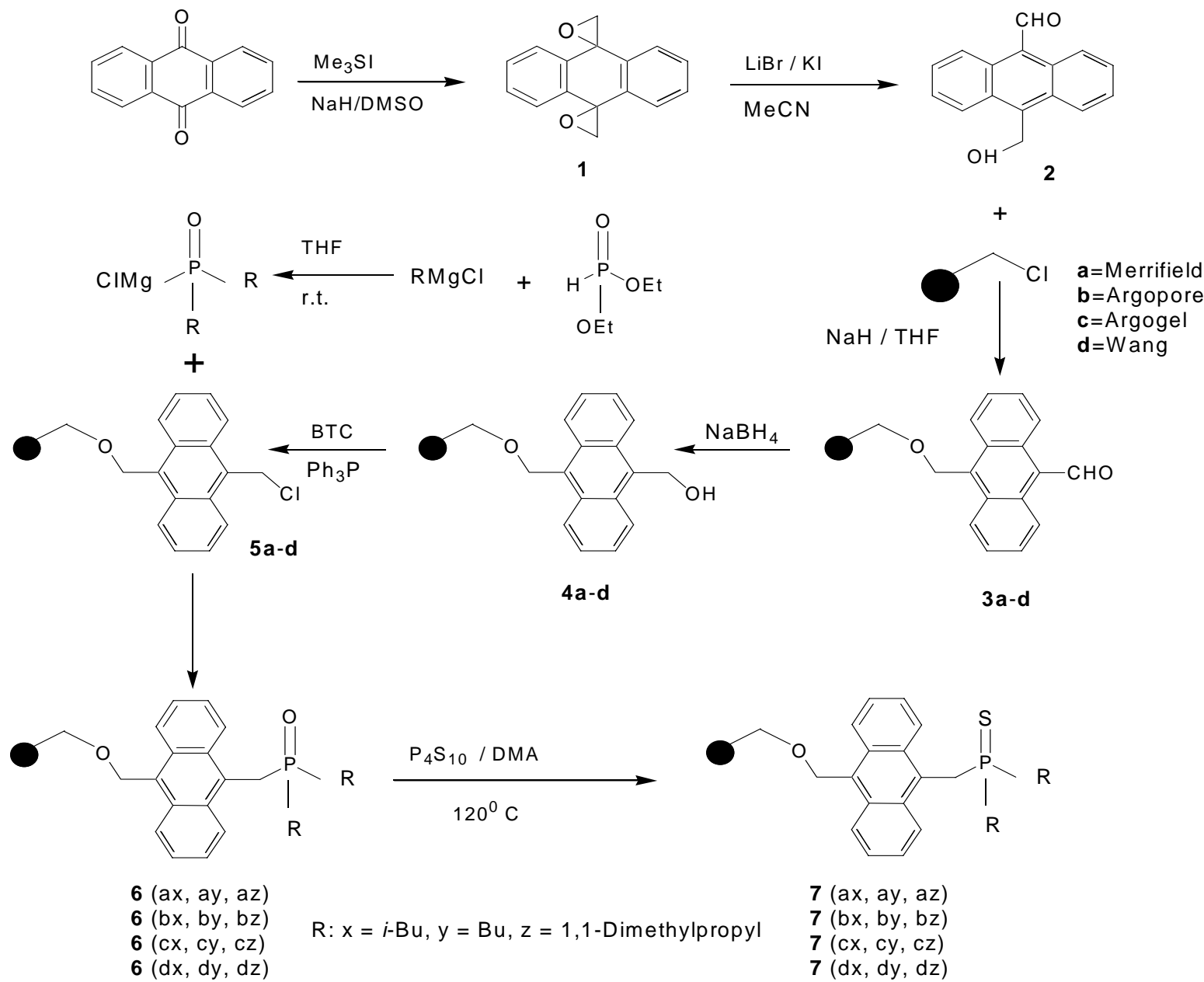

3a-d

\section{Scheme 1}

The library design shown in Table 1 represents a $3 \times 4$ array of metal ion sensing beads with diversity achieved with variations in the solid support and phosphine sulfide substituents.

\section{Mass Spectra Analysis}

Recently, a simple method for the analysis of polymer-supported species based on on mass spectrometry (MS) direct-insertion with electronic impact ionization was developed by our group. ${ }^{17}$ The conditions to operate the instrument such as high temperature and high vacuum, promote the thermal cleavage at the benzylic position of the resins. Polymer degradation does not interfere in the determination of the molecular weight of compounds attached to the resin. Polymer supported compounds 3a-d, 4a-d, and 5a-d were characterized by MS while still bound to the resins, avoiding time-consuming liberations.

Table 1. Library design

\begin{tabular}{|c|c|c|c|c|}
\hline COMPOUND & $\begin{array}{c}\text { Merrifield } \\
\text { Resin }\end{array}$ & $\begin{array}{c}\text { Argopore } \\
\text { Resin }\end{array}$ & $\begin{array}{c}\text { Argogel } \\
\text { Resin }\end{array}$ & $\begin{array}{c}\text { Wang } \\
\text { Resin }\end{array}$ \\
\hline
\end{tabular}




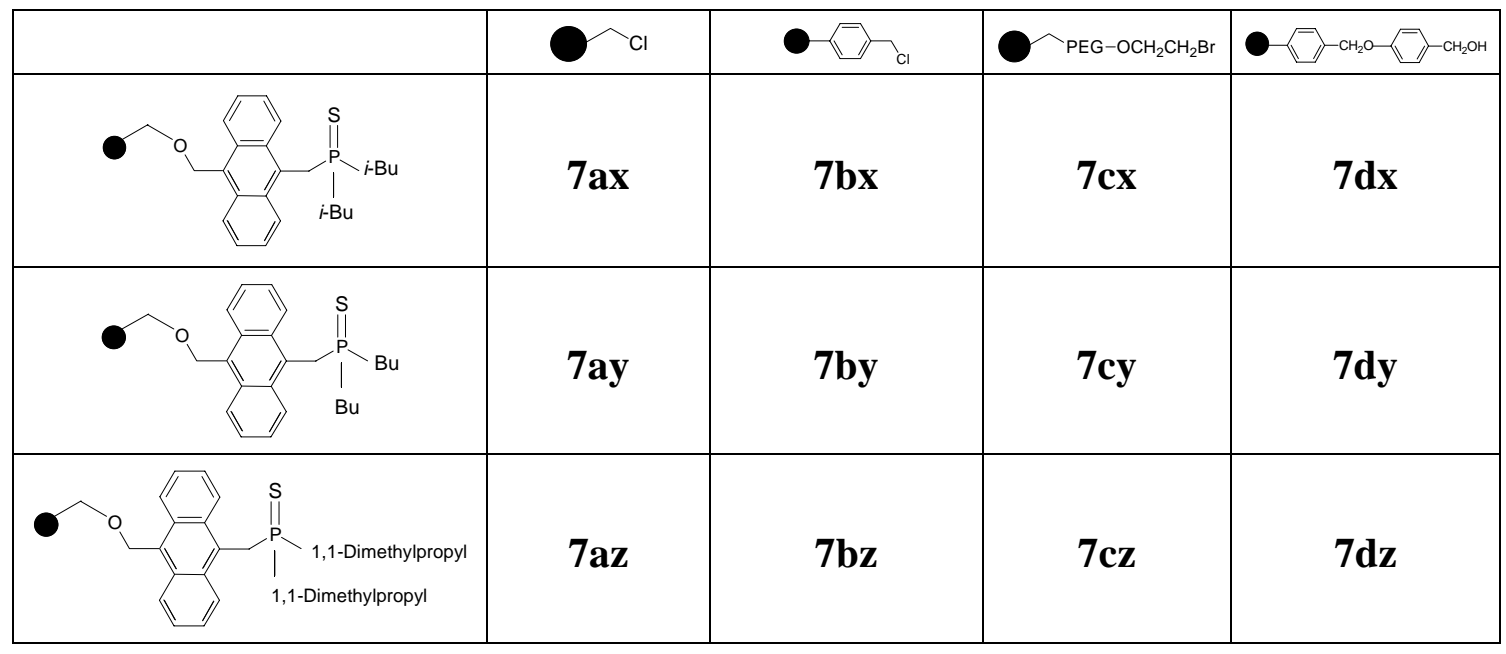

\section{Fluorescence characteristics}

The fluorescence spectral behavior of intermediates 4 and 5, and the final material 7 (Scheme 1), was studied in order to evaluate the influence of the pendant group on the anthracene moiety. Fluorescence intensities at the maximum excitation and emission wavelengths were recorded and are plotted in Figure 1.

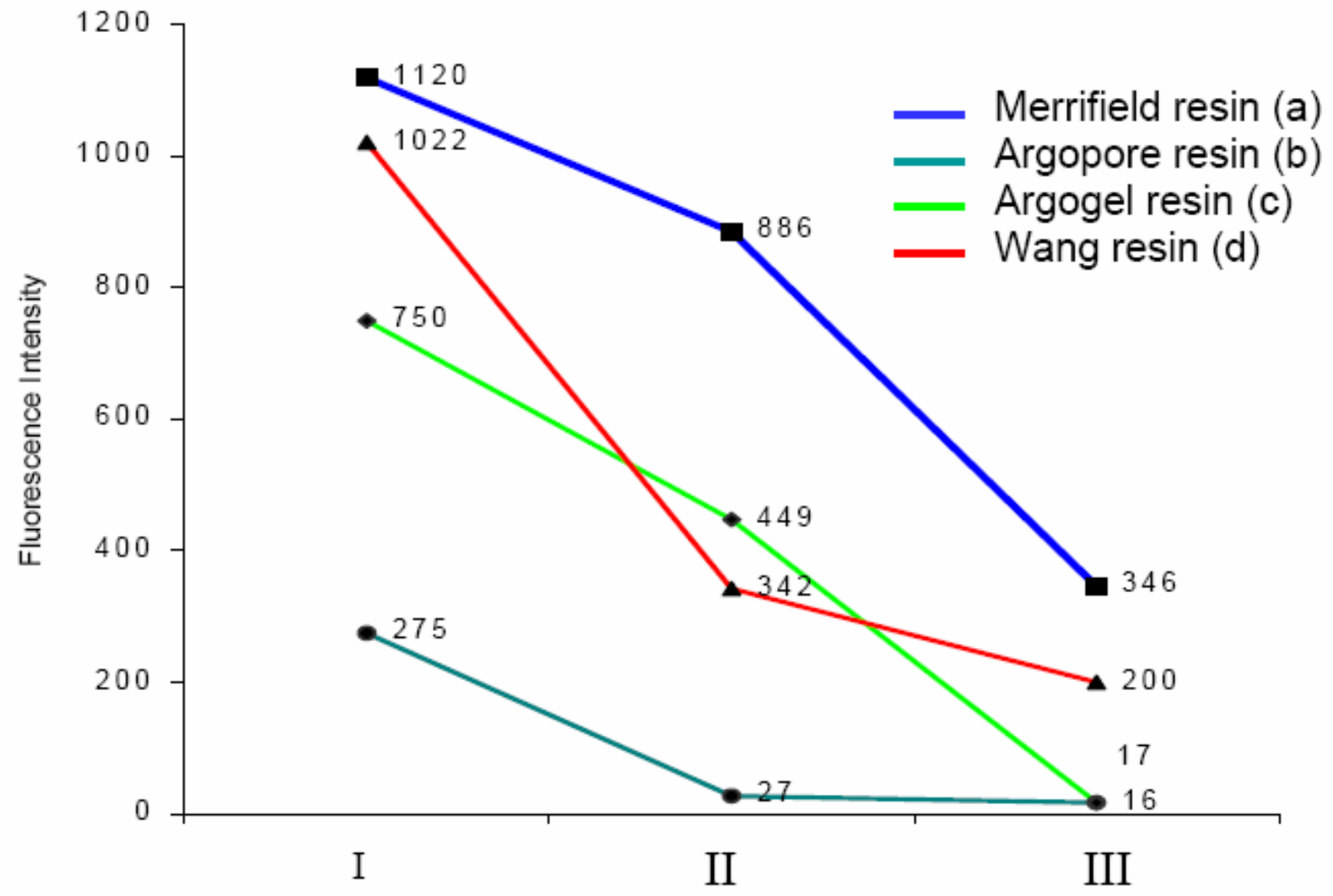

Functional Groups 
Figure 1. Influence of the pendant groups on anthracene fluorescence intensity $[\mathrm{I}=-\mathrm{OH}$ (4); $\mathrm{II}=-\mathrm{Cl}$ (5); III = $i$-butylphosphine sulfide (7)].

As can be seen, the general trend is similar in all the materials assayed: a continuous decrease in fluorescence intensity going from the $-\mathrm{OH}$ group (I) through the $-\mathrm{Cl}$ (II) to the $i$-butylphosphine sulfide (III). This effect could be ascribed to an intramolecular heavy atom effect. Also, a decrease on the fluorescent intensity is observed as the withdrawing effect of the pendant group increases. It is important to notice that the alkyl groups on the phosphine sulfide moiety also play a role in the luminescence properties of the final materials. In fact, as shown in Figure 2 for the Merrifield-based phosphine sulfide materials, the fluorescence is enhanced for the $i$-butyl group. A possible explanation for this effect could be the proximity of methyl groups to the phosphine sulfide centre, the spacer between them being shorter in the case of $i$-butyl. The proximity of methyl groups seems to reverse the heavy atom effect observed above for the phosphine sulfide group.

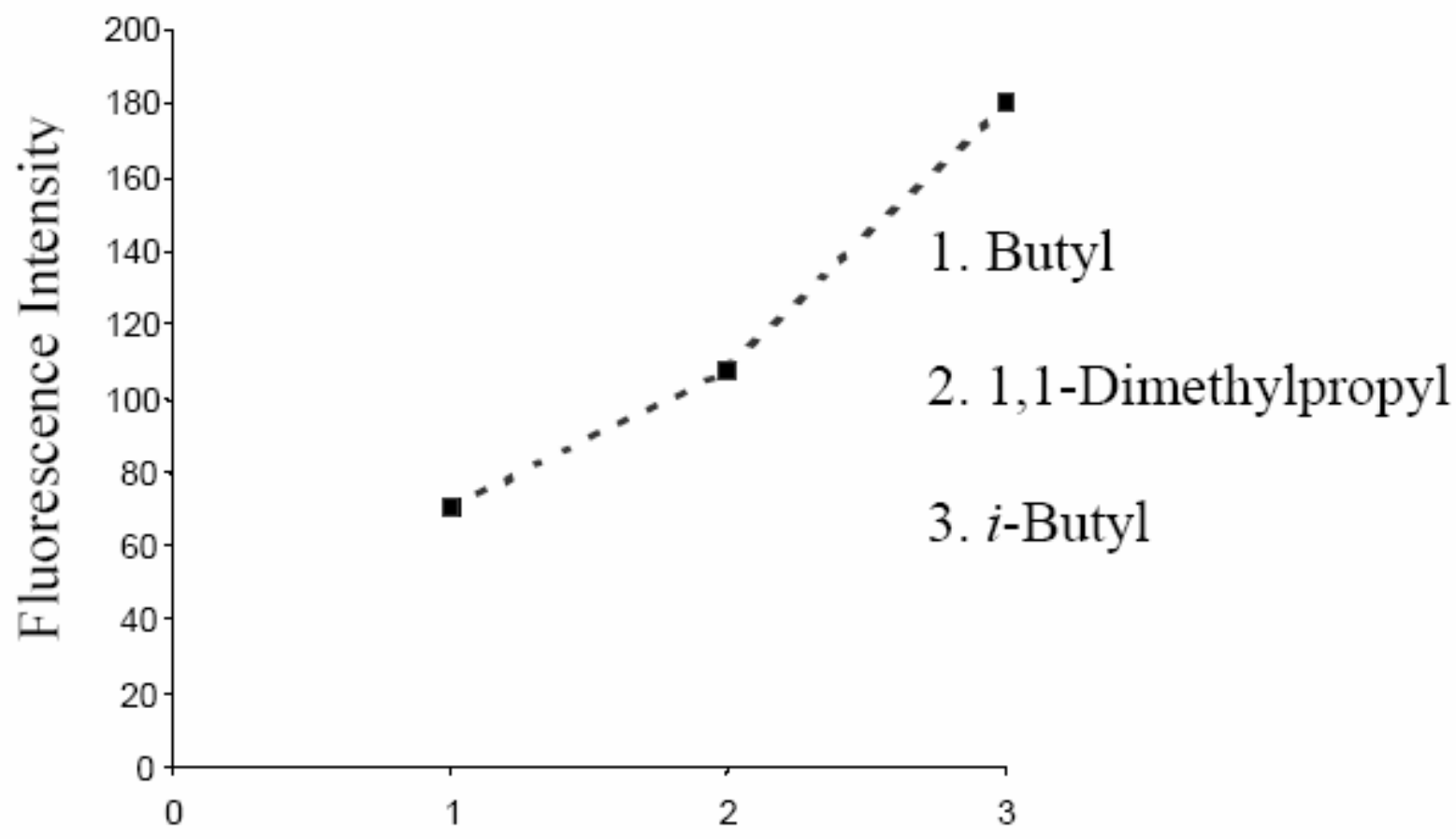

Figure 2. Influence of the alkyl groups bound to the phosphine sulfide moiety on the fluorescence intensity of the sensing Merrifield beads.

The spectral shape for all the sensing phosphine sulfide beads does not depend on the solid support used and follows the same trend; only the fluorescence spectra of the Merrifield-based phosphine sulfide sensing beads are shown in Figure 2. The spectra do not show the pattern of the structured bands of the anthracene moiety. Both excitation and emission spectra are red shifted. A possible explanation could be the formation of intramolecular excimers among anthracene moieties. To validate these results, we tested intermediates $3, \mathbf{4}, \mathbf{5 , 6}, \mathbf{7 a}$-d. Only the resin-phosphine sulfide products 7a-d showed positive response (Figure 3 ). 
The properties of these materials as sensing phases were studied as packing beads into a conventional flow-through cell. Metal ions introduced by flow injection produce a quenching of fluorescence and the response is reversible. Figure 3 shows the analytical results for copper determination in a FIA approach with detection limits of $41 \mu \mathrm{g} / \mathrm{mL}(\mathrm{Cu})$ and $53 \mu \mathrm{g} / \mathrm{mL}(\mathrm{Pb})$, repeatability of $2 \%$ and $4 \%$ (at $100 \mu \mathrm{g} / \mathrm{mL} \mathrm{Cu}$ and Pb level), respectively, and linear calibration up to $200 \mu \mathrm{g} / \mathrm{mL}$ for $\mathrm{Cu}$ (II) and $300 \mu \mathrm{g} / \mathrm{mL}$ for $\mathrm{Pb}(\mathrm{II})$. Reversible quenching signals were observed for copper at $\mathrm{pH} 7.7$ and for lead at $\mathrm{pH}$ 2.0. Therefore, this sensing material may be used as selective recognition sensing phase for these metals ions.

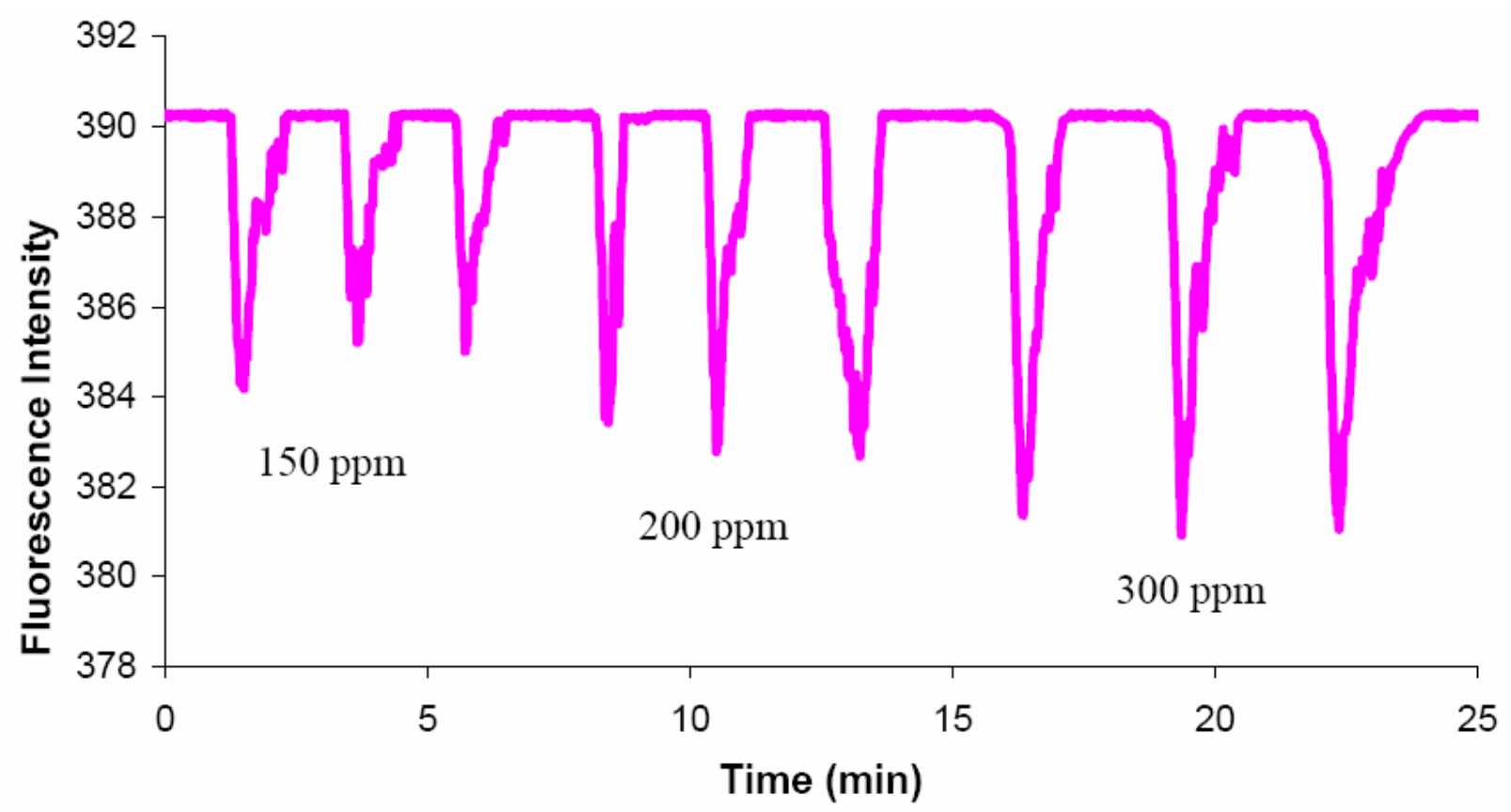

Figure 3. Flow Injection Analysis for Merrifield-phosphine sulfide sensors at three different concentrations of $\mathrm{Cu}$ (II) standard solutions.

\section{Conclusions}

A combinatorial library of diverse alkyl-phosphine sulfides bound to different solid supports was synthesized and their physical-chemical properties evaluated. It was found that the nature of the phosphine sulfide alkyl group plays an important role in the fluorescence quantum yield of the anthraquinone-based luminescent materials, while the solid support seemed to be of minor influence. The obtained phosphine sulfide-anthracene resins could be used as a selective recognition sensing phase for $\mathrm{Pb}(\mathrm{II})$ and $\mathrm{Cu}(\mathrm{II})$.

\section{Experimental Section}


General Procedures. The Merrifield $(1.19 \mathrm{mmol} / \mathrm{g})$, Wang $(1.21 \mathrm{mmol} / \mathrm{g})$, Argopore (0.96 $\mathrm{mmol} / \mathrm{g}$ ) and Argogel $(0.47 \mathrm{mmol} / \mathrm{g})$ resins were purchased from Aldrich Chem. Co. Melting points were determined on an Electrothermal 88629 apparatus and are uncorrected. Infrared (IR) spectra were taken on a Perkin Elmer FT-IR 1600 spectrometer. ${ }^{1} \mathrm{H}$ and ${ }^{13} \mathrm{C}$ nuclear magnetic resonance spectra were recorded on a Varian Mercury $200 \mathrm{MHz}$ Spectrometer in $\mathrm{CDCl}_{3}$ with TMS as internal standard. Mass spectra were obtained on a Hewlett Packard 5989 MS Spectrometer at $70 \mathrm{eV}$ by direct insertion. ESI Mass Spectra were obtained on a Agilent 1100 MSD Ion Trap spectrometer. Elemental Analyses were performed by Numega Resonance labs. San Diego, CA. Combinatorial Chemistry was carried out in a Quest Reactor Argonaut model SLN-210. The Fluorescence spectra were obtained on a Shimadzu RF-5301 PC spectrometer.

9,10-Anthracendiepoxide (1). To a solution of trimethylsulfonium iodide $12.78 \mathrm{~g}(62.43 \mathrm{mmol})$ in DMSO (20 mL) was added NaH (72.09 mmol), anthraquinone (5.0 g, $24.03 \mathrm{mmol})$ in DMSO (20 $\mathrm{mL}$ ), and the reaction mixture was heated at $60^{\circ} \mathrm{C}$ for $3 \mathrm{~h}$. The final mixture was diluted with water $(100 \mathrm{~mL})$ and extracted with DCM $(3 \times 70 \mathrm{~mL})$. The organic phases were combined and washed with water $(2 \mathrm{X} 50 \mathrm{~mL})$. The organic layer was dried over anhydrous sodium sulfate and the solvent removed under vacuum. Crystallization from $\mathrm{Et}_{2} \mathrm{O}$ gave 9,10-anthracendiepoxide (1) (4.1 g, yield 82 \%). Mp. $125^{0} \mathrm{C}$, IR (KBr): 3040, 1951, 1652, $1320 \mathrm{~cm}^{-1} .{ }^{1} \mathrm{H}-\mathrm{NMR}\left(\mathrm{CDCl}_{3}, 200 \mathrm{MHz}\right): \delta$ 7.37(s, 8H), 3.24 (s, $\left.4 \mathrm{H}, \mathrm{CH}_{2} \mathrm{O}\right)$ ppm. ${ }^{13} \mathrm{C}-\mathrm{NMR}\left(\mathrm{CDCl}_{3}, 200 \mathrm{MHz}\right): \delta 135.2,128.2,122.1,69.0,54.5 \mathrm{ppm}$. EIMS m/z [M $\left.\mathrm{M}^{+}\right] 236$ (1), 208 (100), 180 (91), 152 (69).

10-Hydroxymethyl-anthracene-9-carbaldehyde (2). To a solution of 9,10-anthracendiepoxide ( $2.0 \mathrm{~g}, 8.47 \mathrm{mmol})$ in acetonitrile $(100 \mathrm{~mL}) \mathrm{LiCl}(0.716 \mathrm{~g}, 16.94 \mathrm{mmol})$ was added; the mixture was stirred and refluxed for $20 \mathrm{~h}$. The reaction mixture was cooled to $4^{0} \mathrm{C}$ and added $\mathrm{CH}_{2} \mathrm{Cl}_{2}(50 \mathrm{~mL})$. A white solid was obtained by filtration (1.49 g, yield $75 \%$ ). IR (KBr): 3396, 1667, $1259 \mathrm{~cm}^{-1} .{ }^{1} \mathrm{H}-$

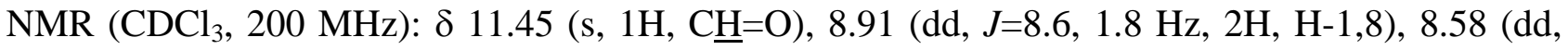
$J=8.3,2.2 \mathrm{~Hz}, 2 \mathrm{H}, \mathrm{H}-4,5), 7.67$ (m, 4H, H-2, 3, 6, 7), 5.50 (s, 1H, O ), 5.50 (s, 2H, $\underline{\mathrm{C}}_{2}-\mathrm{O}$ ) ppm.

${ }^{13} \mathrm{C}-\mathrm{NMR}\left(\mathrm{CDCl}_{3}, 200 \mathrm{MHz}\right): \delta$ 193.5, 137, 129.8, 128.9, 128.8(2CH,1C), 127.5 (2C), 126.2(4CH), 60.8 ppm. EIMS m/z [M+'] 236 (88), 208 (10), 207 (62), 189 (27), 179 (100), 152 (12).

\section{General method for the synthesis of anthracene-phosphine sulfide supported materials based on Merrifield, Argopore, Argogel, and Wang, resins}

PS-10-oxymethyl-anthracene-9-carbaldehyde (3a-d). Merrifield resin $(1.0 \mathrm{~g}, 1.19 \mathrm{mmol})$ was swollen in DMF $(10 \mathrm{~mL})$, then added 10-methanol-9-anthracen-carboxaldehyde $(0.281 \mathrm{~g}, 1.19$ $\mathrm{mmol})$ and $\mathrm{NaH}(0.071 \mathrm{~g}, 1.75 \mathrm{mmol})$. The mixture was heated to $96^{\circ} \mathrm{C}$ and stirred for $6 \mathrm{~h}$. The reaction mixture was then cooled to RT, filtered, and the resin washed with DFM, $\mathrm{MeOH}, \mathrm{H}_{2} \mathrm{O}$, $\mathrm{MeOH}$ and $\mathrm{DCM}(3 \times 5 \mathrm{~mL}$ each). The other resins were treated in the same way. The resins were dried under high vacuum. Polymer-supporting yields were calculated according to Volhard titration of the residual chlorine content in the resin. ${ }^{18}$

(3a): $0.94 \mathrm{~g}$ (73 \%), 79 \% conversion. IR (KBr): 1676, $1152 \mathrm{~cm}^{-1}$. EIMS (m/z): $\mathrm{M}^{+} 236$ (23), 208 (100), 207 (28), 179 (31), 152 (52). 
3b: 0.96 g (74 \%), 77 \% conversion. IR (KBr): 1664, 1155, $\mathrm{cm}^{-1}$. EIMS (m/z): $\mathrm{M}^{+} 236$ (13), 219 (10), 208 (50), 194 (44), 180 (62), 165 (37), 152 (70).

3c: 1.01 g (78 \%), $80 \%$ conversion. IR (KBr): 1656, 1109, $\mathrm{cm}^{-1}$. EIMS (m/z): $\mathrm{M}^{+} 236$ (10), 208 (20), 207 (40), 179 (60), 152 (65).

3d: 1.1 g (84 \%), 82 \% conversion. IR (KBr): 1677, 1157, $\mathrm{cm}^{-1}$. EIMS (m/z): $\mathrm{M}^{+} 236$ (15), 208 (21), 207 (44), 179 (63), 152 (72).

PS-10-Oxymethyl-anthracen-9-yl)-methanol (4a-d). Resins 3a-d (0.50 g, $0.59 \mathrm{mmol})$ were swollen in methanol $(10 \mathrm{~mL})$, and added $3 \mathrm{M}$ solution of $\mathrm{NaBH}_{4}$ in methanol $(30 \mathrm{~mL})$. The mixture was stirred for $1 \mathrm{~h}$ at $0{ }^{\circ} \mathrm{C}$ and refluxed for $6 \mathrm{~h}$. The reaction mixture was cooled to room temperature and filtered. The resins were washed with $\mathrm{MeOH}, \mathrm{H}_{2} \mathrm{O}, \mathrm{MeOH}$ and $\mathrm{DCM}(3 \times 25 \mathrm{~mL}$ each), then dried under high vacuum:

4a: 0.45 g (90 \%). 92 \% conversion. IR (KBr): 3447, 1181, $\mathrm{cm}^{-1}$. EIMS (m/z): $\mathrm{M}^{+} 238$ (12), 224 (15), 208 (70), 194 (31), 180 (39), 152 (61).

4b: 0.47 g (94 \%). 90 \% conversion. IR (KBr): 3426, 1174, $\mathrm{cm}^{-1}$. EIMS (m/z): $\mathrm{M}^{+} 238$ (14), 208(65), 207 (60), 179 (35), 152 (58).

4c: 0.46 g (92 \%). 90 \% conversion. IR (KBr): 3474, 1106, $\mathrm{cm}^{-1}$. EIMS (m/z): $\mathrm{M}^{+} 238$ (18), 208 (62), 207 (42), 179 (62), 152 (55).

4d: 0.49 g (98 \%). >98 \% conversion. IR (KBr): 3452, 1185, $685 \mathrm{~cm}^{-1}$. EIMS (m/z): $\mathrm{M}^{+} 238(10)$, 208 (40), 207 (2), 179 (60), 152 (44).

PS-10-Oxymethyl-9-chloromethyl-anthracene (5a-d). To a stirred solution of triphenylphosphine (3.8 g, $14.52 \mathrm{mmol})$ in dry DCM $(25 \mathrm{~mL})$ at $0^{\circ} \mathrm{C}$, BTC $(1.6 \mathrm{~g}, 4.84 \mathrm{mmol})$ was slowly added over a period of $5 \mathrm{~min}$. The mixture was stirred for an additional $30 \mathrm{~min}$. The solvent was removed under reduced pressure, and the solid was redisolved in DCM $(10 \mathrm{~mL})$. The solution was added dropwise to the resins $4 \mathbf{a}-\mathbf{d}(4.0 \mathrm{~g}, 4.76 \mathrm{mmol})$ previously swollen in dry DCM $(20 \mathrm{~mL})$ and the reaction mixture was refluxed for $2 \mathrm{~h}$. The reaction mixture was cooled to RT, filtered and the resin was washed with DCM, MeOH, $\mathrm{H}_{2} \mathrm{O}$ and DCM $(3 \times 15 \mathrm{~mL}$ each). The resins were dried under high vacuum. Yields were calculated according to Volhard titration of chlorine content in resins. ${ }^{18}$

5a: 3.8 g (98 \%). IR (KBr): 3023, 1595, 536, $\mathrm{cm}^{-1}$. EIMS (m/z): $\mathrm{M}^{+}$256(19), 208 (9), 207(44), 189 (57), 179 (35), 152(70).

5b: 3.6 g (92 \%). IR (KBr): 3052, 1601, 536, $\mathrm{cm}^{-1}$. EIMS (m/z): M+ 256 (21), 208 (10), 207 (40), 189 (55), 179 (23), 152 (60).

5c: 3.9 g (99 \%) IR (KBr): 3052, 1115, 543, $\mathrm{cm}^{-1}$. EIMS (m/z): $\mathrm{M}^{+} 256$ (22), 208 (16), 207 (43), 189 (58), 179 (29), 152 (66).

5d: 3.8 g (95 \%). IR (KBr): 3052, 1152, $547 \mathrm{~cm}^{-1}$. EIMS (m/z): $\mathrm{M}^{+} 256$ (27), 208 (44), 207 (33), 189 (60), 179 (54), 152 (76).

PS-10-Oxymethyl-9-(diisobutyl-phosphine oxide-methyl)-anthracene (6ax-dx). In a three necked flask, diethyl phosphonate ( $1 \mathrm{~mL}, 7.75 \mathrm{mmol}$ ) was slowly added to a magnetically stirred suspension of isobutylmagnesium chloride $(20 \mathrm{~mL}, 40 \mathrm{mmol})$ in anhydrous THF $(60 \mathrm{~mL})$ under nitrogen atmosphere. The temperature was maintained at 20-30 ${ }^{\circ} \mathrm{C}$ for $1 \mathrm{~h}$. Resins 5a-d $(0.5 \mathrm{~g}, 0.59$ $\mathrm{mmol}$ ) were added and the mixture was refluxed for $15 \mathrm{~h}$. The reaction mixture was cooled to room temperature, filtered and the resin was washed with $(4 \times 25 \mathrm{~mL})$ each of the following mixtures: (5 $\%)$ acidic water-dioxane (1:1), acetone-dioxane (1:1), dioxane, ether-dioxane (1:1) and ether. The 
resins were dried under high vacuum. Yields and IR data are presented for Merrifield-based materials. Yields were calculated according to Volhard titration of chlorine content in resins. ${ }^{18}$ The resins were reacted with TFA/DCM (1:1) to promote liberation and then analyzed by HPLCESIMS.

6ax: 0.49 g (98 \%). 88 \% conversion. IR (KBr): 3080, 1602, $1166(\mathrm{P}=\mathrm{O}) \mathrm{cm}^{-1}$. ESIMS (m/z): 361 $\left[\mathrm{M}\left(\mathrm{C}_{23} \mathrm{H}_{37} \mathrm{OP}\right)+\mathrm{H}\right]^{+}$.

6bx: 0.46 g (92 \%). 82 \% conversion. IR (KBr): 3052, 1605, $1160(\mathrm{P}=\mathrm{O}) \mathrm{cm}^{-1}$. ESIMS (m/z): 361 $\left[\mathrm{M}\left(\mathrm{C}_{23} \mathrm{H}_{37} \mathrm{OP}\right)+\mathrm{H}\right]^{+}$.

6cx: 0.47 g (94 \%). 86 \% conversion. IR (KBr): 3052, 1166, $1109(\mathrm{P}=\mathrm{O}) \mathrm{cm}^{-1}$. ESIMS (m/z): 361 $\left[\mathrm{M}\left(\mathrm{C}_{23} \mathrm{H}_{37} \mathrm{OP}\right)+\mathrm{H}\right]^{+}$.

6dx: 0.46 g (92 \%). 91 \% conversion. IR (KBr): 3052, 1166, $1109(\mathrm{P}=\mathrm{O}) \mathrm{cm}^{-1}$. ESIMS (m/z): 361 $\left[\mathrm{M}\left(\mathrm{C}_{23} \mathrm{H}_{37} \mathrm{OP}\right)+\mathrm{H}\right]^{+}$.

PS-10-Oxymethyl-9-(diisobutyl-phosphine sulfide-methyl)-anthracene (7ax-dx). Phosphorous pentasulfide ( $0.66 \mathrm{~g}, 1.48 \mathrm{mmol}$ ) was added to magnetically stirred suspension of polymer $\mathbf{6 a x}-\mathbf{d x}$ $(0.475 \mathrm{~g}, 0.52 \mathrm{meq}$ de $\mathrm{P})$ and $N, N$-dimethylaniline $(30 \mathrm{~mL})$. The mixture was stirred and heated at $120{ }^{\circ} \mathrm{C}$ for $15 \mathrm{~h}$. The polymer was filtered and washed with $(4 \times 25 \mathrm{~mL})$ each of the next mixtures: (5\%) acidic water-dioxane (1:1), acetone-dioxane (1:1), dioxane, ether-dioxane (1:1) and ether. The resins were dried under high vacuum. Yields and IR data are presented for Merrifield-based phosphine sulfide materials. The resins were reacted with TFA/DCM (1:1) to promote liberation and then analyzed by HPLC-ESIMS.

7ax: 0.47 g (95 \%). 76 \% conversion. IR (KBr): 3058, 1602, $590(\mathrm{P}=\mathrm{S}) \mathrm{cm}^{-1}$. ESIMS (m/z): 377 $\left[\mathrm{M}\left(\mathrm{C}_{23} \mathrm{H}_{37} \mathrm{PS}\right)+\mathrm{H}\right]^{+}$. Anal. calcd. for polymer-supported: C, 87.91; H, 7.06; S, 2.08. Found; S, 1.58 7bx: 0.49 g (99 \%). 71 \% conversion. IR (KBr): 3052, 1152, $595(\mathrm{P}=\mathrm{S}) \mathrm{cm}^{-1}$. ESIMS (m/z): 377 $\left[\mathrm{M}\left(\mathrm{C}_{23} \mathrm{H}_{37} \mathrm{PS}\right)+\mathrm{H}\right]^{+}$. Anal. calcd. for polymer-supported: C, 89.74; H, 5.59; S, 1.93. Found; S, 1.37

7cx: 0.37 g (74 \%). 65 \% conversion. IR (KBr): 3052, 1109, $592(\mathrm{P}=\mathrm{S}) \mathrm{cm}^{-1}$. ESIMS (m/z): 377 $\left[\mathrm{M}\left(\mathrm{C}_{23} \mathrm{H}_{37} \mathrm{PS}\right)+\mathrm{H}\right]^{+}$. $]^{+}$. Anal. calcd. for polymer-supported: C, 77.54; H, 7.91; S, 1.29. Found; S, 0.84

7dx: 0.47 g (96 \%). 68 \% conversion. IR (KBr): 3052, 1109, $592(\mathrm{P}=\mathrm{S}) \mathrm{cm}^{-1}$. ESIMS $(\mathrm{m} / \mathrm{z}): 377$ $\left[\mathrm{M}\left(\mathrm{C}_{23} \mathrm{H}_{37} \mathrm{PS}\right)+\mathrm{H}\right]^{+}$. $]^{+}$. Anal. calcd. for polymer-supported: C, 88.00; H, 7.01; S, 2.05. Found; S, 1.39 The sulphur percentage indicates the presence of total content of isobutyl-phosphine sulfide bound to the resins.

\section{Supplementary material available on page 232}

\section{Acknowledgments}

We gratefully acknowledge support for this project by Consejo Nacional de Ciencia y Tecnología, México (CONACyT, GRANT No. 28488-E) and Consejo Nacional de Educación Tecnológica, México (COSNET, GRANT No. 623.97-P). Marisela Castillo ${ }^{19}$ thanks CONACyT for a graduate fellowship. The authors are indebted to Miguel Parra-Hake, Daniel Chávez for encouragement and Marta E. Garcia for technical support. 


\section{References and Notes}

1. Dickinson, T. A.; Walt, D. R.; White, J.; Kaver, S. Anal. Chem. 1997, 69, 3413.

2. (a) Furka, A.; Sebestyen, F.; Asgedom, M.; Dibo, G. Abstr. 14th Int. Congr. Biochem. Prague, Czechoslovakia 1988, 5, 47. (b) Hougthen, R.A.; Pinilla,C.; Blondele, S.E.; Appel, J.R.; Dooley, C.T.; Cuervo, J.H. Nature 1991, 354, 84. (c) Lam, K.S.; Salmon, S.E.; Hersch, E.M.; Hruby, V.J.; Kaznierski, W.M.; Knapp, R.J. Nature 1991, 354, 82. (d) Merrifield, R.B. J. Am. Chem. Soc. 1963, 65, 2149.

3. de Silva A. P.; Dixon I. M.; Gunaratne, H. Q. N.; Gunnlaugsson, T.; Maxwell, P.R. S.; Rice, T. E. J. Am. Chem. Soc. 1999, 121, 1393.

4. Torrado, A.; Walkup, G. K.; Imperiali, B. J. Am. Chem. Soc. 1998, 120, 609.

5. Hennrich, G.; Sonnenschein, H.; Resch-Genger, U. J. Am. Chem. Soc. 1999, 121, 5073.

6. Dujols, V.; Ford, F.; Czarnik, A.W. J. Am. Chem. Soc. 1997, 119, 7386.

7. Sandor, M.; Geistmann, F.; Schuster, M. Anal. Chim. Acta 1999, 388, 19.

8. Cattrall, R.W.; Gregorio, C.C.; Webster, R.D. Anal. Chem. 1997, 69, 3353.

9. Hidalgo, M.; Masana, A.; Freiser, H.; Al-Bazi, S. J.; Valiente, M. Anal. Chim. Acta 1991, 251, 233.

10. Hidalgo, M.; Masana, A.; Salvado, V.; Muñoz, M.; Valiente, M. Talanta 1991, 38, 483.

11. Hidalgo, M.; Masana, A.; Salvado, V.; Muñoz, M.; Valiente, M.; Muhammed, M. Solvent Extr. Ion. Exc. 1990, 8, 491.

12. Chatterjee, A.; Marinsky, J. A. J. Phys. Chem. 1963, 67, 41.

13. Vélez-López, E.; Pina-Luis, G.; Suárez-Rodríguez, J.L.; Rivero, I.A.; Díaz-García, M.E. Sensors and Actuators: B. Chemical 2003, 90, 256.

14. Cooper, Ch. R.; James, T.D. Chem. Commun. 1997, 1419.

15. Rivero, I.A.; Somanathan, R.; Hellberg, L.H. Synthetic Commun. 1993, 23, 711.

16. Congost, M.A.; Salvatierra, D.; Marques, G.; Bourdelande, J.L.; Fony, J.; Valiente, M.; Reactive and Functional Polymers 1985, 28, 191.

17. Chávez, D.; Ochoa, A.; Madrigal, D.; Castillo, M.; Espinoza, K.; González, T.; Vélez, E.; Meléndez, J.; García D.; Rivero, I. A. J. Comb. Chem. 2003, 5, 149.

18. Stewart, J. M.; Young, J. D.; Barany. G. Solid Phase Peptide Synthesis; W.H. Freeman; San Francisco, 1969.

19. Taken in part from the $\mathrm{PhD}$ thesis of Marisela Castillo. 